\title{
MERTK Gene
}

National Cancer Institute

\section{Source}

National Cancer Institute. MERTK Gene. NCI Thesaurus. Code C24591.

This gene plays a role in tissue homeostasis and mutations in the gene are associated with the onset of autosomal recessive retinitis pigmentosa. 